guided in their appraisal of business structure and activities by masters in the field; and the value of the published results to young men who must acquire their knowledge concerning business from books. But one is unable to see wherein it makes that addition to the fund of knowledge which is expected of research; or to treatises, too few in number, which instruct how this or that responsibility in enterprise should be organized and executed, the petty miscellany of background data being spared the reader.

Increasing attention has been paid of late to top executive organization and control. The few other books concerning that area of management have stimulated the same reaction in this reviewer. They are presented as the results of research, but have consisted largely of quantitative descriptions of this or that aspect of management, rather than quantitative discussions of comparative values. This reviewer recalls having recently required students to purchase one of these as a text, and at the end of the course wondering whether he had not led them to throw away the purchase price. Read them in the library, yes; but where is the permanent value? If scholars are not prepared to publish research results as qualitative discussions of the subject matter, they might well hold back the research data until they are so prepared.

\section{New York City}

Cox, Reavis. The Economics of Instalment Buying. Pp. xiii, 526. New York: The Ronald Press Company, 1948. \$6.00.

In this book the author has brought together within the compass of one volume a brief; explanatory account of the rise of installment selling, a critical description of the practices and policies followed in the field, and an analysis of the economic and social consequences of installment selling. In all three of these divisions of his book the author has drawn extensively upon existing literature on the subject, but it should not be inferred from this fact that the book is simply eclectic. Typically the author has chosen pertinent passages from friend and foe of installment selling on specific subjects, analyzed the positions in the light of available statistics or on the basis of logic, and attempted to arrive at the most defensible conclusions. The effect of this treatment is to make the book a compendium of information on installment credit. The text is liberally, but not laboriously, footnoted. The foregoing may seem to suggest hard reading, but the author has succeeded admirably in turning out a work which, in view of its substance, is easy to follow. It should be recorded that the author has supplemented available materials with a significant amount of original research. In a general way he has attempted to direct his research toward those subjects on which existing data are inadequate. In this respect the study distinctly advances the boundaries of knowledge. At many points, however, the author is still forced to admit that data are not available, are inadequate, or perhaps can never be secured.

As the author frankly admits in the preface, this study was undertaken at the request of, and financed by funds from, the Retail Credit Institute of America, for which organization the author is director of research projects. As far as the reviewer could ascertain, this affiliation has not resulted in a biased presentation; although, as might be expected, the author is at very most a friendly critic of installment credit. In passing, it may be observed that his conclusions would probably be accepted with less question if the study had been financed by a disinterested group.

In the opinion of the reviewer the title of the book is more restrictive than its coverage. The study deals with history, practices, and policies as well as with the economics of installment credit. Also, although in the preface the author defends his use of the term "Instalment-Buying," it seems to the reviewer that this suggests a greater emphasis on installment credit from the consumer's point of view than is borne out by the contents.

The book contains 60 tables-some of them quite elaborate-as well as 45 pages of appendixes. There is also an excellent selected bibliography on installment buying.

This is a book that will appeal especially to practitioners and students of installment 
credit. It is an excellent reference source, but is probably too limited in scope for textbook use. It is a good example of the kind of thorough study of a marketing practice which is needed as a basis for improving the process of distribution.

J. H. WestrNG

\section{University of Michigan}

Mund, Vernon A. Open Markets, an Essential of Free Enterprise. Pp. xi, 272. New York and London: Harper \& Brothers, 1948. $\$ 3.00$.

Dr. Mund is the author of an earlier work on Monopoly: A History of Theory. In Open Markets he essays an inductive approach to the problem of monopoly in the American economy. The main body of the work consists of a historical survey of the rise and decline of open markets in Europe and the United States. This survey includes a cursory review of practices in the ancient world; a more detailed treatment of the medieval period; a tracing of later changes in British policy; a brief chapter on the rise of markets in America; and finally an intensive examination of the rise, practices, and consequences of industrial combinations in this country.

To the author, this historical material indicates that an indispensable condition of competitive prices and free economic enterprise is open markets for the basic commodities; that is, markets characterized by (1) centralization of the forces of demand and supply, (2) the making of transactions openly and publicly, and (3) the right of all persons to buy and sell. The historical study shows further that it is not sufficient for the government to provide enterprisers with the right of competition. It must also create the possibility of fair competition among them. The medieval system made provision for carrying on transactions "regularly and openly and by judgment and justice"; but under the system of monopolistic privileges such rules and customs were mostly destroyed.

Today, capitalism based on "free enterprise" is working badly because, over vast areas, business lacks the most essential feature of determining prices-a system of properly functioning markets. Within these areas dominant business interests create their own methods and morals, and business transactions are conducted privately, with secret prices and discounts, discriminatory pricing, concerted action on prices, refusal to sell to some buyers, and unwillingness on the part of independent sellers to compete for fear of punitive measures by large combinations. Industries and groups which do not enjoy such monopolistic advantages appeal to government for special favors. Such private and governmental control makes for an artificial stability at unduly high prices, reduces production, and creates unemployment and unused capacity.

Open markets are the last hope of capitalism. History teaches that such markets are not likely to arise and function unless preserved, encouraged, and regulated by state action. Hence it is the important economic task of government today to supplement its antitrust policy by creating open markets for basic commodities. Under the Common Law there is no question of the legality of such action. Suitable agencies would be the Department of Agriculture for farm products and the Federal Trade Commission for industrial commodities. Dr. Mund outlines constructive measures necessary for building up these new markets. He observes that history shows that open markets are no illusory ideal; they once existed here and they can be created again. Most Americans want free enterprise, full employment, and equal economic opportunity. We can have them if we are willing to pay "this price."

The author's thesis is well (if somewhat repetitiously) argued, is placed in long historical perspective, and is buttressed by much factual material. Its adequacy as a cure for all the ills of capitalism may be questioned, but its presentation is both timely and challenging.

Paul S. Peirce

Winter Park, Florida

Konecky, Eugene. The American Communications Conspiracy. Pp. 168. New York: Peoples Radio Foundation, 1948. $\$ 1.00$.

I can think of no valid reason for sug- 